\title{
Feature
}

\section{Infusing Active Learning into the Large-enrollment Biology Class: Seven Strategies, from the Simple to Complex}

\author{
Deborah Allen* and Kimberly Tanner ${ }^{\dagger}$
}

\author{
*Department of Biological Sciences, University of Delaware, Newark, DE 19716; †San Francisco State University, \\ San Francisco, CA 94132
}

The greatest single challenge to SMET pedagogical reform
remains the problem of whether and how large classes can be
infused with more active and interactive learning methods. Elaine Seymour (2001)

Science educators are urged (National Research Council [NRC], 1997, 2003; National Science Foundation, 1996) to adopt active-learning strategies and other alternatives to uninterrupted lecture to model the methods and mindsets at the heart of scientific inquiry, and to provide opportunities for students to connect abstract ideas to their real-world applications and acquire useful skills, and in doing so gain knowledge that persists beyond the course experience in which it was acquired. While these and other calls for reform dangle the carrot of promised cognitive gains before us (Bransford et al., 1999), the process of translating their message into the realities of practice in given classroom contexts remains a challenge of considerable magnitude. Perhaps because the inquiry-oriented methods that offer the most promise (Edgerton, 2001; Smith, K.A., et al., 2005) were often developed in small-class settings, the gap between promise and practice can seem almost impossible to close in the large-enrollment class environment that still predominates in the introductory course offerings of many colleges and universities. The conditions that led to creation of the large-enrollment class, particularly in research universities, are still with us (Edgerton, 2001) and are not likely to change in the foreseeable future. Thus, although the environment of a large class is not an easy one in which to thrive-either for the instructors who teach them (Carbone and Greenberg, 1998) or for the students who take them (Seymour and Hewitt, 1997; Tobias, 1990) - it is most probably here to stay.

Unfortunately, traditional lecture-dominant methods often fail to motivate the meaningful intellectual engagement that is the central mission and hallmark of the college experience (Smith, K.A., et al., 2005) and that is a crucial factor in students' personal and academic development (Light, 2001). In fact, when large class instructors rely solely on traditional forms of instruction, " . . . the individuals learning the most in this classroom are the professors. They have reserved for themselves the very conditions that promote learning: actively seeking new information, organizing it in a meaningful way, and having the chance to explain it to others" (Huba and Freed, 2000).

DOI: 10.1187 / cbe.05-08-0113

Address correspondence to: Deborah Allen (deallen@udel.edu).
But moving out from behind the relative safety of the lecture podium to adopt the types of active strategies that shift classroom emphasis away from teachers' teaching toward students' participation and learning is often an unsettling prospect, even in the small-class setting. Everyone has heard those real or apocryphal tales of hapless professors who responded to "the call," then were laid low by the ironic onslaught of student anxiety, resistance, or downright anger when the students were presented with classroom activities that aimed to shift emphasis from memorization and recall to the building of critical thinking skills, and the skill and ability to conduct self-directed learning (Felder and Brent, 1996).

Added to the difficulties inherent with instructor and student adjustment to new teaching and learning paradigms are the cogent and interrelated issues of resources and rewards (Boyer Commission on Educating Undergraduates in the Research University for the Carnegie Foundation for the Advancement of Teaching, 1998). The faculty member using inquiry-oriented instruction is often faced with the need to develop new curricula to supplement or replace a reliance on textbooks, a task for which she or he may have received little prior training. The organizational tasks and grading responsibilities inherent in large-class instruction may seem multiplied by an unmanageable order of magnitude when implementation of even the most basic of active-learning strategies is contemplated. It is no wonder that many college and university professors, often faced with the struggle to achieve effective practice in both the teaching and research arenas and thus considerable time constraints, choose the default position of the lecture, with its predictability and efficiency at imparting information. In effect, they may feel caught between a rock and a hard place when confronted with the increasingly more frequent and cogent calls for change in the way science is taught (NRC, 1997, 2003; National Science Foundation, 1996).

Fortunately, the strategies for breaking down the roadblocks and realizing the promise of active learning and inquiry instruction in the large class are being tested and publicized (Handelsman et al., 2004). Educators who have addressed the multitude of issues that underlie implementation of active-learning strategies in large-enrollment settings are conscientiously spreading the word to the science education community by presenting at conferences or publishing in science education journals (Allen and Tanner, 2005).

In previous columns we have discussed a few of the multitude of strategies encompassed by the term "active 
learning." In this one, we will focus on the large-class setting, providing an overview of tried-and-true approaches for incorporating active learning, ranging from the simple to complex. We will highlight those that have been implemented in the lecture classroom itself, rather than those that make use of small-enrollment lab and discussion sections, or of virtual environments such as electronic bulletin boards and computer-based learning modules. Although some seemingly fearless individuals have adapted problem-based learning (PBL) or the case study method to large-class settings (Donham et al., 2001; Reddy, 2000; Shipman and Duch, 2001), we will focus for the most part on strategies and activities that typically do not require such a radical reframing of current standard practice, and are therefore more readily accessible to most science educators. In addition, a description of the general practices for effective teaching in large-class environments is beyond the scope of this column. For excellent guides and materials for this broader set of strategies, we invite the interested reader to consult the Web sites of the many centers for teaching and learning that have also made these resources available to the larger community (e.g., Center for Teaching Effectiveness, University of Maryland, 2004; Faculty Center for Teaching, University of North Carolina, Charlotte, 2000; Gleeson, 1999; Teaching and Educational Development Institute, University of Queensland, 2005).

\section{"BOOKENDING" THE LECTURE WITH QUESTIONS THAT FOCUS STUDENT DISCUSSION}

We all ask our students questions in order to probe their knowledge-albeit the questions are sometimes effectively rhetorical (Allen and Tanner, 2002) or inadvertently addressed to a subset of the class population (Tanner and Allen, 2005). A relatively easy departure point for instructors who want to preserve the lecture-based approach as the central classroom instructional feature is to expand the scope of these questions to require more than a simple yes-no answer, to provide a framework for them that invites student participation, and to judiciously sprinkle them into the lecture at roughly 10- to 20-minute intervals, the duration of the average listener's attention span (Bonwell and Eison, 1991). Typically, when this strategy is used in a 50-minute class period, several short (3-4 minute) discussion sessions, prompted and focused by questions, are evenly interspersed between three (10-12 minute) blocks of lecture, with a 5-minute period at the end for summary of the class session. Alternatively, these sessions can be inserted at the start and end of class (as well as in the middle), effectively "bookending" a lecture period (Smith, K.A., et al., 2005).

A structured question-and-response period is the simplest and shortest type of active-learning activity: one that can be used effectively by even the most introverted of professors (Felder, 1997). It is also a relatively easy passage into active learning from the perspective of organizational and preparation time-the time needed is relatively small. Additionally, there need not be any formal grading mechanism to assess students' work, other than to connect to the questions posed during class sessions, and therefore reinforce their importance, by including them on the usual course exams.
Questions that can form the basis of a short, activelearning activity can be posed directly to individual students by asking them to write a minute-paper structure (e.g., following presentation of a key experiment, asking how they might interpret the experimental data being shown), followed by a brief whole-class processing period, or it can be structured as the turn-to-your-partner discussion commonly known as think-pair-share (Angelo and Cross, 1993). Alternatively, various handbooks (Silberman, 1996) provide ideas for dressing up these more basic focused-discussion/ active-learning frameworks in a multitude of student attention-grabbing ways. In all cases, a brief, instructor-led, whole-class discussion typically follows the student-centered activity, an effective way to provide feedback to students on their responses and make additional connections to the lecture material. By breaking up the lecture with these short question-processing periods, instructors can shift some of the intellectual work to the students - during these sessions, they offer the explanations, organize and summarize the course material, and find ways to fit new information into their existing conceptual frameworks.

But there is a major caveat to achieving these potential outcomes-good outcomes require good questions, and framing and asking good questions is hard. Close-ended questions that probe whether students have understood the lecture they have just heard are useful, but are not as effective at fostering student interactivity or reflection. More complex, open-ended questions not only can up the ante, pushing for greater intellectual and personal growth (Felder, 1997; Freedman, 1994), but have been found to be far more effective prompts for generating small-group discussions (Panitz, 1996). Use of small, cooperative learning groups for processing questions can take away some of the anxiety that students may experience on opening up their mouths in a large class - they can try out their ideas first among a smaller group of their peers. Reporting back as a spokesperson for a group is less daunting than voicing a personal opinion. Even more importantly, the increased student interactivity that results has been found to be an important factor in affecting students' personal and academic development (Astin, 1993; Springer et al., 1999). If these groups are temporary and ad hoc, lasting only a single class session, the impact on the instructors' organizational load is relatively benign.

As mentioned above, piggy-backing instructor-led discussions onto student-active, question-response sessions can provide valuable feedback, while sparing the instructor additional grading responsibilities. However, the downside of this approach is that it makes it hard for the instructor to get a sense of students' collective response patterns. A simple technique that requires only a minimal amount of preparation can help. Individual students or student groups are given a set of colored index cards, each color responding to the "a," " $b$," "c," etc., responses of a multiple-choice question. On request, the students hold up the card corresponding to their chosen response to the instructor's question. The instructor can gain a quick impression of the pattern of student responses, or literally count cards. If the questions are substantive, this permutation of the familiar "raise your hand if you think this is the right answer" strategy can provide yet another structure for conducting question-prompted student discussions to bookend lectures. 


\section{CLASSROOM TECHNOLOGY FOR “ON-THE- SPOT FEEDBACK" WITHOUT GRADING PAINS}

Suppose a large-class instructor wants to have permanent documentation of students' individual and collective response patterns to these simplest of possible active-learning activities, ones that are built on the foundation of a good question? The value added by such documentation is well known-it can help students to chart their progress and teachers to plan future instruction, and can add variety to the course portfolio of summative assessment strategies that contribute to a student's grade. Is this added value worth the additional cost of grading time? While only the individual course instructor knows the right answer to this question, use of classroom technology can help tip the balance toward a "yes" response.

For example, in his "team learning with informative testing" approach, Michaelsen (1992) reported using multiple-choice testing of understanding of preassigned reading for assurance of student preparation for complex active-learning tasks, and to foster student-to-student accountability within learning teams. He streamlined this process for large-class use by bringing a portable scanning machine to class (one capable of storing data on individual response patterns), and running the scantrons through it immediately after students completed their responses. A lower-tech variation on this theme of giving students immediate feedback is the scratchable scantron. Students process their responses like lottery tickets, scratching off the surface film over the bubble of their choice to reveal whether that choice is the correct one. If it is not, they may go on to select alternative responses with sequentially lower point values, until they have chosen the correct one (Bush, 2001). These methods can be used as preludes to complex active-learning activities (Herreid, 1994; Michaelsen, 1992) or in concert with the more simple types of activelearning activities, such as those described in the previous section, used to periodically break out of the lecture rut.

Another, more advanced classroom technology for providing instructional feedback in a large class with only minimal grading pain, is the use of student response (clicker) systems (Wood, 2004). Each student or student team is given a wireless, handheld response pad that sends student responses to a receiver at the instructor's computer station via an infrared or radio signal. Student response patterns can be stored, tabulated, and graphed relatively quickly. In addition, individual (with students identified anonymously by number) or collective class responses can be displayed nearly instantaneously to the class for immediate feedback and discussion. In the case of complex questions that connect with common student misconceptions, initial responses can be redisplayed for a side-by-side comparison with a second round of responses to the same question (Wood, 2004). The reasons for particular choices can become the basis for class discussion leading to better understanding of the implications of the course material. These systems can engage students in the material through survey, practice, review, or pretest of course material and through personal interactions with peers and the instructor. The instructor now has a record of the alternate conceptions that can be used to plan future instruction, or he or she can use the stored data on individual responses for assigning points toward the students' grades (or both). For the interested reader, Knight and Wood (2006) more fully describe how they use these strategies in a large-enrollment developmental biology course in this issue of Cell Biology Education.

Again, it should be noted that the cognitive benefits to be reached using these informative testing strategies are only as strong as the questions asked, and multiple-choice questions are a particularly difficult format in which to pose questions that nudge students to the realm of higher order thinking-a potential downside for the instructor who does not have access to a ready supply of these questions. In addition, the records do not provide explanations of the reasons or reasoning patterns for students' selection of particular choices-if this information is needed, it must be obtained from essays or interviews of individual students or from whole-class discussions.

\section{STUDENT PRESENTATIONS AND PROJECTS}

Another approach for the large-enrollment class is to devote nearly the entire class meeting time to student presentations and projects. A readily accessible variation on this type of activity was designed for a 170-student introductory biology course (Eisen, 1996). Students (approximately 10-15 per week) research and write reports on the "disease of the week," and must be prepared to provide short summaries to the class as called for in the course of that week's lectures.

Eisen (1998) reports on a more ambitious model for using student presentations-one in which the course is almost entirely given up to this type of learning strategy. He uses it in a college sophomore- and junior-level course in cell biology with an enrollment of 60-100 students. The 60- to 75minute class periods are divided into time for two student presentations on research articles from the recent primary literature, chosen to follow the typical topical sequence in cell biology textbooks. Students, who work in teams of three to four members for the presentations, also lead the follow-up question-and-answer-type class discussions. Nonpresenting students are held accountable for the subject matter of the presentations on course exams. The instructor chooses the articles, provides some resources, meets with students outside of class as a consultant on quality-control issues, and gives brief orienting lectures at the start of each class. Science literacy goals are fostered because students research, review, and present background material as well as key features of their assigned research studies.

In courses of this type, the instructor's role is largely displaced to behind the scenes, outside of class activities such as planning and coaching presentation teams. Periodic formal and informal feedback from students on their perceptions of the course can provide information that can help the instructor to address any student concerns that may result (see next section).

\section{LEARNING-CYCLE INSTRUCTIONAL MODELS}

When classroom use of more complex active-learning activities, ones that present students with new cognitive challenges, begin to supplant more and more of the class time formerly devoted to the instructor's direct explanations, student response is often mixed. Many students, when faced with these new academic and intellectual challenges, voice concerns that the instructor appears to be doing less teaching, and that the course appears unorganized by contrast with the predictable structure and pace of lectures 
(Felder, 1997). Often, students will express doubts about their ability to direct their own learning, and report a sense of learning less course content than they did in previous lecture-based classes (Goodwin et al., 1991); consequently, they are worried about success in future courses. Use of learning-cycle instructional models is one way to address these very real student concerns without compromising ambitious objectives and goals for student learning (Allard and Barman, 1994; Ebert-May et al., 1997).

The most common of these learning-cycle approaches in use in the sciences is the five-phased " $5 \mathrm{E}$ " instructional model. The phases of the cycle typically play out as follows: the first phase, engagement, aims to draw the students in with a reading, video clip, provocative question, or other short activities designed to connect to and perhaps organize prior knowledge in preparation for new learning. The content that is introduced also connects to the central topics of the lesson. In the second phase, exploration, additional learning tasks focus on concepts and skills necessary to understand these central topics. The third phase, explanation, builds on the first two phases, providing additional examples and opportunities for students to demonstrate their understanding. The fourth phase, elaboration, seeks to deepen student understanding by providing new applications and implications of the central concepts and processes of the lesson. Student understanding is evaluated in the fifth and final stage. For the interested reader, Ebert-May et al. (1997) provide an example (instructor teaching strategies and student activities) of how they use this 5E model to teach topics related to photosynthesis in their large-enrollment introductory biology classes. In their model, students work in cooperative learning groups throughout the cycle.

Clearly, the use of learning-cycle instructional models, particularly in combination with cooperative learning groups, requires a not inconsiderable investment of time for curriculum design and organizational tasks. The major advantage of these models in large classrooms, however, is that they are constructed on the basis of thoughtful consideration of how people acquire new knowledge and build conceptual frameworks (Allard and Barman, 1994), and on the need to invite students to learn by connecting to their prior experiences and ideas. They do this in a way that provides a clear-cut mechanism for integrating a variety of both traditional and creative instructional strategies along a student-to-instructor-centered spectrum. The familiar terrain of instructor-centered lectures can be visited, giving the instructor a reassuringly visible presence when it is most likely to be useful (e.g., in the explanation phase), without undermining the development of students' ability to direct their own learning. The instructor's grading workload, generated during the evaluation phase, can be kept manageable by use of peer-review strategies, formative assessment (instructor looks over student work and offers comments to the whole class but does not assign a grade), and group assignments. Individual accountability among group members can be fostered by inclusion of material from learning-cycle activities on exams.

\section{PEER-LED TEAM LEARNING}

Another way to address student concerns when activelearning activities increase in complexity and intensity is to enlist the help of their near peers, typically students who have taken the course before, to help guide students' efforts (Allen and White, 2001; Sarquis et al., 2001; Smith, A.C., et al., 2005). In addition to working with students by serving as facilitators of one or more cooperative-learning groups, near peers may lead supplemental instruction sessions for students who need additional encounters with course content or practice with building requisite skills, or participate in aspects of course and curriculum design, or both. They support students through moments of uncertainty with inquiry-based learning, they can and do attest to the benefits foreseen by the instructor's goal setting and intents, and often, they voluntarily assume the role of mentors in broader aspects of the students' undergraduate experiences. Typically, the peer facilitators efforts are in turn guided and supported by in-service training sessions (for which course credit can be awarded), which include topics such as group dynamics, giving and receiving constructive feedback, and underlying philosophies and goals of inquiry-oriented instructional methods, as well as in the objectives and background content of specific course activities (Allen and White, 2001; Sarquis et al., 2001).

\section{MODELING INQUIRY APPROACHES IN THE LARGE CLASS}

Central to the message inherent in the various calls for action for change in science instruction is the notion that acquisition of science literacy is essential for all students, whether or not they intend to become practicing scientists (American Association for the Advancement of Science, 1989). If these science literacy goals include an understanding of how scientists organize, conduct, and interpret the results of their investigations, they are particularly hard to achieve in largeenrollment nonmajors courses in which students are not enrolled in a concurrent laboratory course that can provide concrete experience. Some instructors have found a way around this limitation (Uno, 1990) by excerpting short laboratory activities; if necessary, reframing them in inquiry-based modes, and creating "kits" of materials for their implementation in the lecture classroom. By logistical necessity, these activities need to be relatively sparing of materials and complex instrumentation-for example, an activity in which students explore the ecosystem-level interactions between photosynthesis and respiration in a series of test tube ecosystems (an activity designed for high school that was adapted for use with college-level nonmajors by one of the authors; Education Development Center, 1998). Despite this necessity for simplicity, students can exercise the intellectual power behind designing aspects of the experiment, predicting outcomes that would lend support to their hypotheses, and analyzing and interpreting their findings. These strategies clearly are easier to conduct in a setting in which preparatory staff, teaching assistants, and a small storage room annexed to the lecture classroom are available.

\section{PROBLEM-BASED LEARNING AND CASE STUDIES}

While PBL and the case study method seem easier to manage in a small-class setting, there are some examples of their adaptation to the large-class environment. (Donham et al., 2001; Shipman and Duch, 2001). Briefly, in the classic model of PBL, students use a learning-cycle approach as they work together in small groups to resolve complex, real-world 
scenarios. The problems launch students' learning, on a need-to-know basis. As originally formulated, in the case study method, the instructor leads a whole-class discussion about student insights into a contextually rich dilemma or situation requiring extensive analysis that requires application of content previously learned by other means (Herreid, 1994). As these methods have been adapted to undergraduate contexts, the original distinctions between them have become blurred. Additional adaptations for the large class include using problems and cases that provide natural break points for instructor guidance at 15- to 20-minute intervals, instructor-led whole-class discussions (added to PBL) and short lecturettes, and use of peer group facilitators (Allen and White, 2001).

\section{PULLING IT ALL TOGETHER -WORKSHOP BIOLOGY}

In many introductory course experiences, activities designed to teach "science as inquiry" are often relegated to the concurrent laboratory meetings; the lecture meeting provides connections to the lab mostly because the instructor attempts to present central concepts in the same sequence as they are likely to arise as background to deeper understanding of the whys and wherefores of an ongoing lab activity. Workshop Biology (Udovic et al., 2002) is an example of a largeenrollment introductory course for nonmajors in which the science-as-inquiry theme is integrated throughout all course components. The Workshop Biology course experience is designed to convey the message to students that biology is a way of knowing, rather than just a static body of knowledge. A heavy emphasis is placed on helping students to acquire the skills needed to make informed choices consistent with their values on science and technology related matters and issues that arise in their daily lives. As a result, both in lecture (called "assemblies" in Workshop Biology) and lab, activities are investigative in nature-students explore and discover fundamental concepts through asking and answering their own questions, or to do in-depth research and make decisions about current and controversial issues. The activities are often designed to help students, who work in teams, to confront and move beyond common misconceptions in such areas as natural selection, cell division, and cellular energy transformation processes. In addition, the assemblies are aimed to help students integrate this new information, building frameworks to connect and interconnect new ideas and examples to each other and to broader, "big ideas" in biology. The Workshop Biology Web site (Udovic, 1999) provides additional information and downloadable resources relating course format and activities, including concept tests used to assess students' conceptual learning.

\section{LEARNING HOW TO DEVELOP CURRICULUM AND TEACH IN NEW WAYS}

We began this column by acknowledging the efforts of those college and university faculty who have shared the activelearning strategies they have developed and implemented in large-enrollment classes to the broader community by presenting at conferences or publishing in science education journals. We went on to illustrate seven examples, from the simple to the complex, pulling from the science education literature. Despite their good intent, however, journal articles have constraints - they fall short of being "how to do it" manuals for the typical college-level biology instructor who may only have experienced traditional methods of teaching, both as an instructor and while as a student. After reading these articles, or the synopses of them in this column, one may still wonder, "If I'm not at the front of the room lecturing, what will I be doing?" "Are there examples of good questions - the ones that actually cause my students to care about the subject and to talk about it with each other?" "How do I turn a good question into an activity?" "What's the difference between a sequence of lectures and textbook readings and a curriculum unit? Is there one?"

Fortunately, Web sites for faculty teaching workshops and online repositories of course materials, teaching notes, and teaching videotapes have begun to appear that take a step further toward helping to address these questions (e.g., National Center for Case Study Teaching in Science, 2005; Udovic, 1999 [Workshop Biology]; University of Delaware, 2005). Also, in acknowledgment of this need, the National Academies of Science has begun to offer a Summer Institute, sponsored by the Howard Hughes Medical Institute (National Academies of Science, 2005; Wood and Handelsman, 2004) designed to bring together cross-institutional teams of life sciences faculty for an intensive week to design pedagogical approaches, courses, course materials (i.e., teachable units), and assessment strategies geared at the large, introductory course environment. The Institute's sessions provide a mix of individual activities such as reading, writing, and planning, with discussions and workshop-style presentations that model inquiry teaching. These workshops are conducted by experienced teachers, several of whom have authored the literature cited in this column. Institute participants are required to document the effectiveness of their teachable unit in the upcoming academic year; the units will be published in upcoming years.

A particular intriguing aspect of this Summer Institute is that participants are also required to "share the word" in a way aimed at breaking the cycle of "teaching as we were taught." At the Institute participants are provided with materials to offer a seminar in mentoring for graduate students, postdoctoral students, or faculty who will also be teaching in these new ways and with the new materials. Perhaps we are getting closer to a time in which teaching efficiency and productivity will no longer be indexed to how many students at a time we can deliver information to, but rather, to how many students we engage in deep and meaningful learning.

\section{REFERENCES}

Allard, D.W., and Barman, C.R. (1994). The learning cycle as an alternative method for college science teaching. BioScience 44, 99-101.

Allen, D., and Tanner, K. (2002). Answers worth waiting for: one second is hardly enough. Cell Biol. Educ. 1(1), 3-5.

Allen, D., and Tanner, K. (2005). Approaches to biology teaching and learning: from a scholarly approach to teaching to the scholarship of teaching. Cell Biol. Educ. 4, 1-6.

Allen, D.E., and White, H.B. (2001). Peer facilitators of in-class groups: adapting problem-based learning to the undergraduate setting. In: Student Assisted Teaching: A Guide to Faculty-Student Teamwork, ed. J.E. Miller, J.E. Groccia and M.S. Miller. Bolton, MA: Anker Publications. 
American Association for the Advancement of Science (1989). Science for All Americans: Project 2061. Washington, DC.

Angelo, T.A., and Cross, K.P. (1993). Classroom Assessment Techniques: A Handbook for College Teachers. San Francisco: Jossey-Bass.

Astin, A. (1993). What matters in college: Four critical years revisited. San Francisco: Jossey-Bass.

Bonwell, C.C., and Eisen, J.A. (1991). Creating Excitement in the Classroom (ASHE-ERIC Higher Education Report No. 1). Washington, DC: George Washington University, School of Education and Human Development.

Boyer Commission on Educating Undergraduates in the Research University for the Carnegie Foundation for the Advancement of Teaching (1998). Reinventing Undergraduate Education: A Blueprint for America's Research Universities. http://naples.cc.sunysb.edu/ Pres/boyer.nsf (accessed 24 August 2005).

Bransford, J.D., Brown, A.L., and Cocking, R.R. (eds.) and Committee on Developments in the Science of Learning, National Research Council (1999). How People Learn: Brain, Mind, Experience, and School. Washington, DC: National Academies Press.

Bush, M. (2001). A multiple choice test that rewards partial knowledge. J. Further Higher Educ. 25(2), 157-163.

Carbone, E., and Greenberg, J. (1998). Teaching large classes: Unpacking the problem and responding creatively. In: To Improve the Academy Vol. 17, ed. M. Kaplan. Stillwater, OK: New Forums Press and Professional and Organizational Development Network.

Center for Teaching Effectiveness, University of Maryland (2004). Large Classes: A Teaching Guide. http://www.cte.umd.edu/library/ large (accessed 12 May 2005).

Donham, R.S., Schmieg, F.I., and Allen, D.E. (2001). The large and the small of it: a case study of introductory biology courses. In: The Power of Problem-Based Learning: A Practical 'How To' for Teaching Undergraduate Courses in Any Discipline, ed. B.J. Duch, S.E. Groh, and D.E. Allen. Sterling, VA: Stylus Publications.

Ebert-May, D., Brewer, C., and Allred, S. (1997). Innovation in large lectures - teaching for active learning. BioScience 47, 601-607.

Edgerton, R. (2001). Education white paper. http://www. pewundergradforum.org/wp1.html (accessed 26 March 2005).

Education Development Center (1998). It's elemental. In: What on Earth? Insights in Biology Series. Dubuque, IA: Kendall Hunt.

Eisen, A. (1996). 'Disease of the week' reports: catalysts for writing and participation in large classes. J. College Sci. Teaching 24, 331-334.

Eisen, A. (1998). Small group presentations-teaching "science thinking" and context in a large biology class. BioScience 48, 53-58.

Faculty Center for Teaching, University of North Carolina, Charlotte (2000). A Survival Handbook for Teaching Large Classes. http://www.fctel.uncc.edu/pedagogy/focuslargeclasses/ ASurvivalHandbook.html (accessed 18 May 2005).

Felder, R.M. (1997). Beating the numbers game: effective teaching in large classes. Paper presented at the 1997 ASEE Annual Conference, Milwaukee, WI, June 1997. http://ncsu.edu/felder-public/Papers/ Largeclasses.htm (accessed 18 May 2005).

Felder, R.M., and Brent, R. (1996). Navigating the bumpy road to student-centered instruction. College Teaching 44(2), 43-47.

Freedman, R.L.H. (1994). Open-ended Questioning: A Handbook for Educators. New York: Addison Wesley.

Gleeson, M. (1999). Better communication in large courses. In: The Social Worlds of Higher Education, ed. B.A. Pescolido and R. Aminzade. Thousand Oaks, CA: Pine Forge Press. http://www. wmich.edu/\%7Eteachlrn/winter2000/teaching/lgclass.htm (accessed 18 May 2005).
Goodwin, L., Miller, J.E., and Cheetham, R.D. (1991). Teaching freshmen to think-does active learning work? BioScience 41(10), 719-722.

Handelsman, J., Ebert-May, D., Beichner, R., Bruns, P., Chang, A., DeHaan, R., Gentile, J., Lauffer, S., Stewart, J., Tilghman, S.M., and Wood, W.B. (2004). Scientific teaching. Science 304, (23 April 2004), 521-522.

Herreid, C.F. (1994). Case studies in science: a novel method of science education. J. College Sci. Teaching 23(4), 221-229.

Huba, M.E., and Freed, J.E. (2000). Learner-Centered Assessment on College Campuses: Shifting the Focus from Teaching to Learning. Boston: Allyn and Bacon, 35.

Knight, J., and Wood, W.B. (2006). Teaching more by teaching less. Cell Biol. Educ. 4, 298-310.

Light, R. (2001). Making the Most of College. Cambridge, MA: Harvard University Press.

Michaelsen, L.K. (1992). Team learning: a comprehensive approach for harnessing the power of small groups in higher education. To Improve the Academy 11, 107-122.

National Academies of Science (2005). National Academies Summer Institutes on Undergraduate Education in Biology. http://www. academiessummerinstitute.org. (accessed 28 August 2005).

National Center for Case Study Teaching in Science (2005). [Links to information about summer and fall workshop conferences, and to a collection of case study materials and resources.] http://ublib.buffalo. edu/libraries/projects/cases/case.html (accessed 28 August 2005).

National Research Council, Committee on Undergraduate Science Education (1997). Science Teaching Reconsidered: A Handbook. Washington, DC: National Academies Press.

National Research Council, Committee on Undergraduate Science Education (2003). Improving undergraduate instruction in science, technology, engineering and mathematics: Report of a workshop. Washington, DC: National Academies Press.

National Science Foundation (1996). Shaping the Future: New Experiences for Undergraduate Education in Science, Mathematics, Engineering and Technology. Report of the Advisory Committee to the NSF Directorate for Education and Human Resources. Washington, DC.

Panitz, B. (1996). Stuck in the lecture rut? ASEE Prism 5, 26-30.

Reddy, I.K. (2000). Implementation of a pharmaceutics course in a large class using quick thinks and case-based learning. Am. J. Pharm. Educ. 64, 349-355.

Sarquis, J.L., Dixon, L.J., Gosser, D.K., Kampmeier, J.A., Roth, V., Strozak, V.S., and Varma-Nelson, P. (2001). The Workshop Project: peer-led team learning in chemistry. In: Student-Assisted Teaching: A Guide to Faculty-Student Teamwork, ed. J.E. Miller, J.E. Groccia and M.S. Miller. Bolton, MA: Anker Publishing.

Seymour, E. (2001). Tracking the progress of change in U.S. undergraduate education in science, mathematics, engineering, and technology. Sci. Educ. 86, 79-105.

Seymour, E., and Hewitt, N.M. (1997). Talking about leaving. Why undergraduates leave the sciences. Boulder, CO: Westview Press.

Shipman, H., and Duch, B.J. (2001). Large and very large classes. In: The Power of Problem-Based Learning: A Practical 'How To' for Teaching Undergraduate Courses in Any Discipline, ed. B.J. Duch, S.E. Groh, and D.E. Allen. Sterling, VA: Stylus Publications.

Silberman, M. (1996). Active Learning: 101 Strategies to Teach Any Subject. Boston: Allyn and Bacon.

Smith, A.C., Stewart, R., Shields, P., Hayes-Klosteridis, J., Robinson, P., and Yuan, R. (2005). Introductory biology courses: a framework to 
support active learning in large enrollment introductory science courses. Cell Biol. Educ. 4, 143-156.

Smith, K.A., Sheppard, S.D., Johnson, D.W., and Johnson, R.T. (2005). Pedagogies of engagement: classroom-based practices. J. Engr. Educ. January 2005, 1-16.

Springer, L., Stanne, M.E., and Donovan, S.S. (1999). Effect of small group learning on undergraduates in science, mathematics, engineering, and technology. Rev. Educ. Res. 69(1), 21-51.

Tanner, K., and Allen, D. 2004. Learning styles and the problem of instructional selection-engaging all students in science courses. Cell Biol. Educ. 3(4), 197-201.

Teaching and Educational Development Institute, the University of Queensland (2005). Teaching and learning support: teaching large classes. http://www.tedi.uq.edu.au/teaching/toolbox/largeclasses. html (accessed 26 August 2005).

Tobias, S. (1990). They're Not Dumb, They're Different: Stalking the Second Tier. Tuscon, AZ: Research Corporation.
Udovic, D. (1999). Workshop Biology. http://yucca.uoregon.edu/wb (accessed 27 August 2005).

Udovic, D., Morris, D., Dickman, A., Postlethwait, J., and Wetherwax, P. (2002). Workshop biology: demonstrating the effectiveness of active learning in an introductory biology class. BioScience 52(3), 272-281.

University of Delaware (2005). Institute for Transforming Undergraduate Education [with links to Problem Based Learning site and Problem-Based Learning Clearinghouse]. http://www.udel.edu/inst (accessed 28 August 2005).

Uno, G.E. (1990). Inquiry in the classroom. BioScience 40(11), 841843.

Wood, W.B. (2004). Clickers: a teaching gimmick that works. Dev. Cell 7, 796-798.

Wood, W.B., and Handelsman, J. (2004). Meeting report: the 2004 National Academies Summer Institute on Undergraduate Education in Biology. Cell Biol. Educ. 3, 215-217. 